\title{
Problem Analysis of the Contract Farmers and the Contracting Firm under Contract Farming of Bottle Gourd
}

\author{
Arjun Singh Rajput*, Vikalp Sharma and R.C. Sharma \\ Maharana Pratap University of Agriculture and Technology, Udaipur, Rajasthan, India \\ *Corresponding author: arjnrjpt@gmail.com
}

\begin{abstract}
The present investigation was undertaken with a view to study the problems faced by the contract farmers and the contracting firm under contract farming of bottle gourd in the Jaipur district of Rajasthan. The contracting firm Rajasthan olive cultivation limited was selected, as it was only contracting firm in the Bassi tehsil which was engaged in the contract farming related to cucurbits and other vegetables. A list of 26 villages having contract farming in bottle gourd was obtained from the tehsil headquarter. From that list three villages were selected randomly. From these villages, 30 contract farmers were selected randomly and 20 non-contract farmers resembling to the contract farmers except contract component were also selected to make a comparative study of the contract farming vis-à-vis non-contract farming. Primary data were collected for the agricultural year 2015-16. The conventional budgeting technique and multiple regression functions were used to analyze the data. In the production of bottle gourd, contract farmers and contracting firms face many problems like transfer of technology, supply of quality seed, arrangements of institutional credit, fertilizers and other inputs, market arrangements, timely payments, violation of terms and conditions, lack of proper management by the company, frequent price fluctuations in markets, lack of transport facilities during peak periods, etc. For solving such problems it is necessary to first identify the problems and reasons thereof so that corrective measures may be resorted to tackle them. However this study was conducted on simulation conditions that involves the construction of the artificial environment (under control conditions) within which relevant information and data can be generated like in green house, poly house and shade net house for the future scholars.
\end{abstract}

Keywords: contract farming, gross income,irrigation, simulation, written agreement

India has been a predominantly agrarian economy since time immemorial. The growth rate of GDP of agriculture and allied sector declined from 9.6 per cent in 1996-97 to 6.0 per cent in 2005-06 and further 3.6 per cent in 2011-12 to 2.1 per cent in 2017 (Economic survey, 2017-18). India with vegetable production of 176 million tonnes is the second largest producer of vegetables contributing $14 \%$ of world's vegetable production. With an area of 9.5 million hectares under vegetables, the average productivity of vegetables in India is 17.7 tonne/ha in 2013-14. Percentage share of vegetable production in the major vegetable growing states in India are West Bengal (14), Uttar Pradesh (12), Bihar (9), Andhra Pradesh (5), Gujarat (7), Karnataka (5), Tamil Nadu (5), Odisha (6), Maharashtra (6),
Madhya Pradesh (8)and others (23). An area, production and productivity of Rajasthan are 1.4 million ha, 12.709 tonnes and $6.3 \mathrm{t} / \mathrm{ha}$, respectively (Vegetable Statistics - IVRI (2014-2015). All the same, the low and stagnated yield levels of agricultural and horticultural crops, post-harvest losses, lack of proper marketing facilities as well as the poor availability of food articles to consumers have emerged as serious problems before the farmers, the planners and policy makers. The studies conducted by many researchers have suggested that such problems may be, to a great extent, tackled by resorting to contract farming. Contract farming has been and is being practiced in many countries of the world including India. The studies related to the negative aspects of the contract farming, in the 
opinion of the farmers, are that the contracts are biased and enforced strictly, firms provide poor extension services, over-price their services, pass on the risk to the producers, offer low prices of the produce, favour large farmers, delay payments, do not provide compensation for natural calamity loss and do not explain the pricing method. The over exploitation of ground water, salinization of soils, soil fertility decline and soil pollution are some of the typical examples of environmental degradation that crop up due to contract farming. There are many big corporate houses such as Hindustan lever, Pepsi foods, A.V. Thomas, Daburs, Thapars, Marico, Godrej, Mahindra Sulabh, Nijjer agro food Ltd., Wimco, SAB Miller india, ROCL Ltd., etc. that undertake contract farming for many crops apart from several players. ROCL Ltd. entered in the production and marketing of vegetables, fruits and flowers. Among vegetables it cultivate cabbage, cauliflower, strawberry, olive, tomato, squash green/ yellow, chilli, watermelon, bottle gourd, cucumber, etc. under contract farming in the state on 19.04.2007 under the Company Act 1956. The company was constituted in collaboration with the Government of Rajasthan through Rajasthan State Agriculture Marketing Board, Plastro Plasson Industries (India) Limited (now Finolex Plasson Industries (India) Limited), Pune \& Indolive Limited of Israel having equal partnership. Initially, the Government of Rajasthan through Rajasthan State Agriculture Marketing Board \& Plastro Plasson Industries (India) Limited, Pune. In Rajasthan contract farming is done mainly in Jaipur, Jodhpur, Sikar, Ajmer, Ganganager, Kota, Bharatpur, Hanumangar, Alwar, Jhalawar and Udaipur districts. In Jaipur district watermelon, bottle gourd, cucumber, etc. are the major growing cucurbits under contract basis. In Jaipur district Bassi, Jhotwara and Shahpura are the major tehsils for the production of bottle gourd with an area and production of 125 hectare (360qt/ ha), 65 hectare (350qt/ha) and 50 hectare (350qt/ha), respectively. (Source: Krishi pant bhawan, Jaipur)

\section{DATA AND METHODOLOGY}

\section{Selection of the study area and crop}

In Jaipur district contract farming in case of cucurbits was prevalent only in three tehsils namely Bassi, Jhotwara and Shahpura. Among these three tehsils, Bassi tehsil occupies first place in area and production of bottle gourd. Therefore, bottle gourd and bassi tehsil were selected purposively as study crop and study area, respectively.

\section{Sampling procedure}

Multi stage stratified random sampling technique was used for drawing a sample for the present study. At first stage of sampling, the tehsils in the district was selected. At the second stage of sampling, the villages in the tehsil were selected. At the third stage of sampling, the bottle gaurd growers were selected as respondents.

\section{Selection of the villages}

A list of 26 villages having contract farming in bottle gourd was obtained from the tehsil headquarter. From that list three villages namely Dhindon, Damodarpura and Kacholiya were selected randomly.

\section{Selection of the farmers}

A list of 127 bottle gourd growers was prepared with the help of supervisor. Out of 127 bottle gourd growers, 57 were contract and 70 were non-contract farmers. From that list 50 farmers were selected randomly. Out of 50 farmers, 30 farmers were contract and 20 were non-contract.

\section{Selection of the contracting firm}

The contracting firm ROCL Ltd. was selected, as it was only contracting firm in the Bassi tehsil which was engaged in the contract farming related to cucurbits and other vegetables.

\section{Collection of data}

Primary data were collected for the study. The primary data with respect to problems and constraints were collected from the producer farmers, contracting firm, wholesalers-cumcommission agents and retailers through personal interview method with the help of a pretested schedule specifically prepared (standardized) for the purpose.

\section{Analysis of data}

After collection, the data were compiled, tabulated and analyzed according to the selected categories of sample farms. 


\section{Identification of the problems faced by the contract farmers and contracting firm}

Information regarding the problems faced by the contract farmers and the contracting firm were collected by personally interviewing the respondents in question with the help of a set schedules specially designed for the purpose. Garrett's ranking technique was used to arrive at some conclusion.

\section{Garrett's ranking technique}

Garrett's ranking technique was used to analyze the problems faced by contract farmers in bottle gourd production, its marketing and contractual agreement with the firm. The contract farmers were asked to rank the factors that they were facing. The rankings of the factors assigned by the farmers were converted into per cent terms by using the following formula:

$$
\text { Percent position }=\frac{100\left(R_{i j}-0.50\right)}{N_{j}}
$$

where,

$$
\begin{aligned}
& R_{i j}=\text { Rank given for } i^{\text {th }} \text { item by } j^{\text {th }} \text { individual farmer } \\
& N_{j}=\text { Number of items ranked by } j^{\text {th }} \text { individual } \\
& \text { farmer }
\end{aligned}
$$

The percent position of each rank thus obtained was converted into scores by referring to the tables given by Garrett and Woodworth (1969). Then for each problem, the scores of individual farmer were added together and divided by the total number of farmers for whom scores were added. The mean scores for all the problems were ranked by arranging then in descending order.

\section{RESULTS AND DISCUSSION}

\section{Problems faced by the contract farmers}

\subsection{Production problems}

The Table 1 depicts the category wise and overall scenario of problems faced by the contract farmers in bottle gourd production. It is obvious from the table that lack of irrigation water was one of the major problems faced by the sample contract farms of overall size group. It may be attributed to fast depleting water level coupled with irregular and interrupted electricity supply in that area. Category wise small and medium farms ranked this problem as number one. Irregular supply of inputs like fertilizers and plant protection chemicals (excepting seeds) was the second major problem faced by the farms. This may be attributed to production and distribution policies of the government. Small, medium and large farms were reported to have faced this problem. Problems regarding shortage of labour during peak hours of production ranked third on overall size group as well as on large farms because of pre engagement of labour in MNREGA (Mahamta Ghandhi National Rural Employment Gurantee Act) work activities and heavy demand

\begin{tabular}{|c|c|c|c|c|}
\hline \multirow[t]{2}{*}{ S1. No. } & \multirow[t]{2}{*}{ Problems } & \multicolumn{2}{|c|}{ Overall $\mathbf{N}=30$} & \multirow{2}{*}{$\begin{array}{l}\text { Categories of farms showing the rank } \\
\text { in overall scenario }\end{array}$} \\
\hline & & GMS* & Rank & \\
\hline 1 & Lack of irrigation water facility & 52.37 & I & Small, medium \\
\hline 2 & $\begin{array}{l}\text { Irregular supply of inputs like fertilizers and plant } \\
\text { protection chemicals (excluding seeds) }\end{array}$ & 50.86 & II & Small, Medium, Large \\
\hline 3 & Shortage of labour during peak hours of cultivation & 48.12 & III & Large \\
\hline 4 & Insufficient crop insurance coverage & 45.18 & IV & Medium, Large \\
\hline 5 & $\begin{array}{l}\text { Improper (more / less) use of fertilizers and plant } \\
\text { protection chemicals }\end{array}$ & 43.40 & $\mathrm{~V}$ & Small \\
\hline 6 & Wide gap between credit required and credit supplied & 37.05 & VI & None** \\
\hline 7. & Delayed supply of seeds and in required quantity & 35.40 & VII & Small,medium \\
\hline
\end{tabular}
of labour by the farmers cultivating different crops in the study area.

Table 1: Ranking of production problems faced by the contract farmers

${ }^{*}$ Garrett's Mean Scores, N= No. of farmers; ${ }^{* *}$ Wide gap between credit required and credit supplied was reported to be II rank on small, III on medium and large farms. 
So, demand for labour was high and availability of labour was less. Insufficient crop insurance coverage was ranked as fourth major problem on medium, large and on overall farm size groups. Improper (more/less) use of fertilizers and plant protection chemicals ranked fifth on small and overall size groups. The farmers of overall category reported that their existed a wide gap between credit required and credit supplied which was attributed to the due to scale fixed by the banks.

Small, medium and overall size groups of farms reported that seeds were not supplied in time and in required quantity. This was because of late supply of seeds by the Govt. agencies. The similar results were observed by Bhardwaj (2005); Kumar and Kumar (2008); Nagaraj et al. (2008); Swain (2009); Sivagami et al. (2010); Swain (2011) and Prasad et al. (2013).

\subsection{Marketing problems}

The category-wise and overall scenario of marketing problems faced by contract farmers has been depicted in Table 2. The table indicates that the difficulty in maintaining quality standards was major marketing problems on overall size group of contract farms. This may be attributed to biological nature of production of bottle gourd. Medium and large size groups of farms ranked this problem at number one. Market price fluctuations emerged as second important problem on medium, large and overall size groups. This might be attributed to the seasonal nature of crop production which affects the supply and demand of the produce.

Problems of high transportation cost faced by the farmers was ranked third by the overall size groups of the farms. Delay in timely payment was fourth rank by the overall size groups of the farms. Medium, large and overall size group of farms reported that the retailers resorted to cut in weight of the produce due to unlike physical appearance viz. shrinking, contaminated, matured, damaged and infected of the produce. The similar results were reported by Dileep et al. (2002), Agarwal et al. (2005), Bhardwaj (2005), Kumar and Kumar (2008), Nagaraj et al. (2008) and Swain (2011).

\subsection{Contractual problems}

Category wise and overall scenario of contractual problems faced by the contract farmers is presented in Table 3. As is clear from the table, lack of facility (shelter, fencing, scarcity of water for irrigation, electric power supply and long distance of market) on farms was narrated as the major contractual problem on overall as well as on small, medium and large farms. The second major problem that was reported by the small, medium and as well as overall size groups of farms was the payment at the time of agreement. The similar results were observed by Kumar and Kumar (2008) and Swain (2011).

Table 2: Ranking of marketing problems faced by the contract farmers

\begin{tabular}{|c|c|c|c|c|}
\hline \multirow{2}{*}{$\begin{array}{l}\text { Sl. } \\
\text { No. }\end{array}$} & \multirow[t]{2}{*}{ Problems } & \multicolumn{2}{|c|}{ Overall $\mathrm{N}=30$} & \multirow{2}{*}{$\begin{array}{l}\text { Categories of farms showing the rank } \\
\text { in overall scenario }\end{array}$} \\
\hline & & GMS* & Rank & \\
\hline 1 & Difficulty in maintaining quality standards & 52.27 & I & Medium, Large \\
\hline 2 & Market price fluctuations & 49.35 & II & Medium, large \\
\hline 3 & High transportation cost & 48.20 & III & None ${ }^{* *}$ \\
\hline 4 & Delay in timely payment & 46.23 & IV & Small, Medium \\
\hline 5 & $\begin{array}{l}\text { Cut in weight of the produce due to poor } \\
\text { quality standards }\end{array}$ & 38.78 & $\mathrm{~V}$ & Medium, large \\
\hline
\end{tabular}

*Garrett's Mean Scores, N= No. of farmers; ${ }^{* *}$ High transportation cost was reported to be I rank on large, II on medium, III on small farms; *** Delay in timely payment was reported to be III rank on large and medium, IV on small farms.

Table 3: Ranking of contractual problems faced by the contract farmers

\begin{tabular}{|c|c|c|c|c|}
\hline \multirow[t]{2}{*}{ S1. No. } & \multirow[t]{2}{*}{ Problems } & \multicolumn{2}{|c|}{ Overall $\mathrm{N}=\mathbf{3 0}$} & \multirow{2}{*}{$\begin{array}{l}\text { Categories of farms showing the rank in overall } \\
\text { scenario }\end{array}$} \\
\hline & & GMS* & Rank & \\
\hline 1 & Lack of facility on farms & 54.30 & I & Small, medium, large \\
\hline 2 & Payment at the time of agreement & 49.28 & II & Small, medium, large \\
\hline
\end{tabular}

*Garrett's Mean Scores, N=No. of farmers. 


\section{Problems faced by the contracting firm}

Problems faced by contracting firm have been depicted in Table 4. The table indicates that the high cost of maintenance was a major problem. Difficulty in price bargaining and its fixation was the second major problem faced by the firm. The third major problem reported was that the less availability of farm inputs. Market price fluctuations emerged as fourth important problem. Shortage of labour during peak hours of cultivation was the fifth problem. Lack of extension/technical personnel was the last but not the least problem faced by the contracting firm. The similar results were reported by Agarwal et al. (2005) and Kumar and Kumar (2008).

Table 4: Ranking of problems faced by contracting firm $(\mathrm{N}=1)$

\begin{tabular}{rlcc}
\hline $\begin{array}{c}\text { Sl. } \\
\text { No. }\end{array}$ & GMS* & Rank \\
\hline 1 & High cost of maintenance & 75.00 & I \\
2 & $\begin{array}{l}\text { Difficulty in price bargaining and } \\
\text { their fixation }\end{array}$ & 55.33 & II \\
3 & Less availability of farm inputs & 52.33 & III \\
4 & Market price fluctuations & 40.00 & IV \\
5 & Shortage of labour during peak & 38.00 & V \\
hours of cultivation & & \\
6 & $\begin{array}{l}\text { Lack of extension/ technical } \\
\text { personnel }\end{array}$ & 26.00 & VI \\
\hline
\end{tabular}

${ }^{*}$ Garrett's Mean Scores, N= No. of firm.

\section{CONCLUSION}

- Lack of irrigation, irregular supply of inputs like fertilizers and plant protection chemicals, shortage of labour during peak hours of production, insufficient crop insurance coverage, improper (more / less) use of fertilizers and plant protection chemicals, wide gap between credit required and credit supplied and timely non availability of seeds were the main problems faced by the farmers.

- The main marketing problems that were faced by the contract farmers were: (i) quality standards of the produce were not up to expectation, (ii) fluctuations in market price, (iii) high transportation cost (iv) delay in timely payment, and (v) cut in weight of the produce.
- Similarly the problem faced by the contracting firm were reported to be (i) High cost of maintenance, (ii) difficulty in price bargaining and its fixation, (iii) Less availability of farm inputs, (iv) Market price fluctuations, (v) Shortage of labour during peak hours of cultivation, and (vi) lack of extension/technical personnel.

- Contract farmers opined that lack of facility on farmers' fields was the first contractual problem andpayment at the time of agreementin that area the second contractual problems.

\section{REFERENCES}

Agarwal, I, Priya, S. and Bhuvaneswai, S. 2005. Contract Farming Venture in Cotton: A Case Study in Tamil Nadu. Indian Journal of Agricultural Marketing, 19(2): 153-161.

Bhardwaj, S.P. 2005. Enhancing Crop Production by Contract Farming - A Specific Case of Lac Production in India. Indian Journal of Agricultural Marketing, 19(2): 168-169.

Dileep, B.K., Grover, R.K. and Rai, K.N. 2002. Contract Farming of Tomato: An Economic Analysis. Indian Journal of Agricultural Economics, 57(2): 197-210.

Garrett, H.E. and Woodworth, R.S. 1969. Statistics in Psychology and Education, Vakils, Feffer and Simons Pvt. Ltd. Bombay. 329.

Kumar, J. and Kumar, P. 2008. Contract Farming: Prospect and its Effect on Income and Employment. Agricultural Economics Research Review, 21(2): 45-53.

Nagaraj, N., Chandrakanth, M.G., Chengappa, P.G., Roopa, H.S. and Chandakavate, P.M. 2008. Contract Farming and its Implications for Input Supply, Linkages Between Markets and Farmers in Karnataka. Agricultural Economics Research Review, 21(Conference No.): 307-316.

Prasad, H.D.V., Singh, P., Kumar, S. and Singh, B.K. 2013. Performance and Constraints of Gherkin Contract Farming. Indian Research Journal of Extension Education, 13(1): 112-116.

Sivagami, R., Alagumani, T. and Samsai, T. 2010. Integration of Production and Marketing of Maize Through Contract Farming- An Economic Analysis. Indian Journal of Agricultural Marketing, 24(2): 145-151.

Swain, B.B. 2009. Contract Farming and Agricultural Development: A Case Study of Orissa. The IUP Journal of Agricultural Economics, 6(1): 55-63.

Swain, B.B. 2011. Contract Farming in Andhra Pradesh: A Case of Rice Seed and Gherkin Cultivation. Economic and Political Weekly, 46: 42. 
